\title{
PENGARUH MECHANICAL BONDING PADA ALUMINIUM DENGAN SERAT KARBON TERHADAP KEKUATAN TARIK FIBER METAL LAMINATES
}

\author{
Hilmi Iman Firmansyah, Anindito Purnowidodo, Sofyan Arief Setyabudi \\ Teknik Mesin Universitas Brawijaya, Jalan MT. Haryono, 167 - Malang (65145) - Indonesia \\ Telp: +62-341-554291, 587711, Fax: +62-341-554291 \\ E-mail: firmansyahilmie@gmail.com
}

\begin{abstract}
Fiber metal laminates (FML) are composite structures fabricated by combining two layers of surface material with core material. The outer surface of FML used in this composite is Aluminum with Al 1100 type. The FML core material uses carbon fiber. The fabrication process of the composites utilizes vacuum infusion method, in which the resin is infused into the mold with vacuum condition. Bonds between the core and the surface layers are the variables affecting the strength of FML. In this research, the method used to increase the bonds between layers in FML was mechanical method, it's called mechanical bonding. This method involved providing roughness $\left(R_{a}\right)$ on aluminum surface using sand blasting process to produce different roughness variables, with roughness value of 1,68 $\mu \mathrm{m} ; 1,78 \mu \mathrm{m} ; 1,93 \mu \mathrm{m} ; 2,128 \mu \mathrm{m}$ and 2,887 $\mu \mathrm{m}$. The aim of this study was to examine the impact of aluminum surface roughness to tensile strength of fiber metal laminates composites. The highest tensile strength of FML was obtained at 2,887 $\mu \mathrm{m}$ with a value of $367 \mathrm{MPa}$.
\end{abstract}

Keywords: FMLs, vacuum infusion, $R$ a, tensile strength, carbon fiber, mechanical bonding, sand blasting

PENDAHULUAN

Asal kata komposit adalah "to compose" yang berarti menyusun atau menggabung. Sederhananya komposit berarti bahan gabungan dari dua atau lebih bahan yang berlainan. Komposit adalah suatu material yang terdiri dari campuran atau kombinasi dua atau lebih material baik secara mikro atau makro dimana sifat material tersebut berbeda bentuk dan komposisi kimia dari zat asalnya (Smith, 1996). [1]

Matthews dkk. (1993) mendefinisikan komposit adalah suatu material yang terbentuk dari kombinasi dua atau lebih material pembentuknya melalui campuran yang tidak homogen, dimana sifat mekanik dari masingmasing material pembentuknya berbeda.[2] Dari campuran tersebut akan dihasilkan material komposit yang mempunyai sifat mekanik dan karakteristik yang berbeda dari material pembentuknya. Material komposit mempunyai sifat dari material konvensional pada umumnya dari proses pembuatannya melalui percampuran yang tidak homogen, sehingga kita bebas merencanakan kekuatan material komposit yang kita inginkan dengan jalan mengatur komposisi dari material pembentuknya.
Klasifikasi komposit berdasarkan penyusunnya dibedakan menjadi tiga, yang pertama adalah fibrous composites materials (komposit serat) terdiri dari dua komponen penyusun yaitu matriks dan serat, kedua adalah Parcticulate composite materials (komposit partikel) merupakan jenis komposit yang menggunakan partikel/butiran sebagai pengisi dan yang ketiga adalah laminated composites materials atau structural composite materials (komposit berlapis) terdiri dari sekurang kurangnya dua material berbeda yang direkatkan bersama sama.

Fiber metal laminates (FML) adalah struktur komposit hybrid yang komponen penyusunnya merupakan lembaran logam paduan dan lapisan serat polimer sebagai penguat (Sinmazçelik dkk, 2011). Fiber metal laminates merupakan struktur komposit lapis yang menggabungkan keuntungan dari material logam dan matrik yang diperkuat serat (Gambar 1). Material logam yang merupakan isotropic material memiliki sifat mekanik kekuatan dan ketahanan impact yang tinggi namun material logam bersifat korosif, sedangkan material yang secara keseluruhan komposit memiliki karakterisitik kelelahan (fatigue) yang baik kemudian kekuatan dan kekakuan yang tinggi. Kedua material ini yang 
memiliki keunggulan pada sifat mekanisnya masing-masingdikombinasikan menjadi satu material yang disebut fiber metal laminates yang bertujuan memperbaiki kekurangan pada masing-masing material [7].

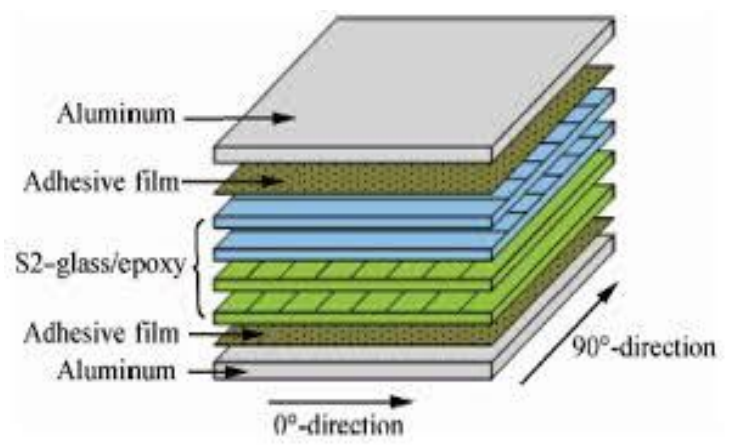

Gambar 1 Fiber metal laminates (FML)

Struktur material ini disusun dengan menggabungkan komposit laminate pada lapisan logam. Fiber metal laminates biasanya tersusun dari aluminium dengan aramid dan fiber glass. Namun juga bisa digunakan material lain sebagai penguat seperti pada gambar 2 yang menjelaskan klasifikasi dari fiber metal laminates.

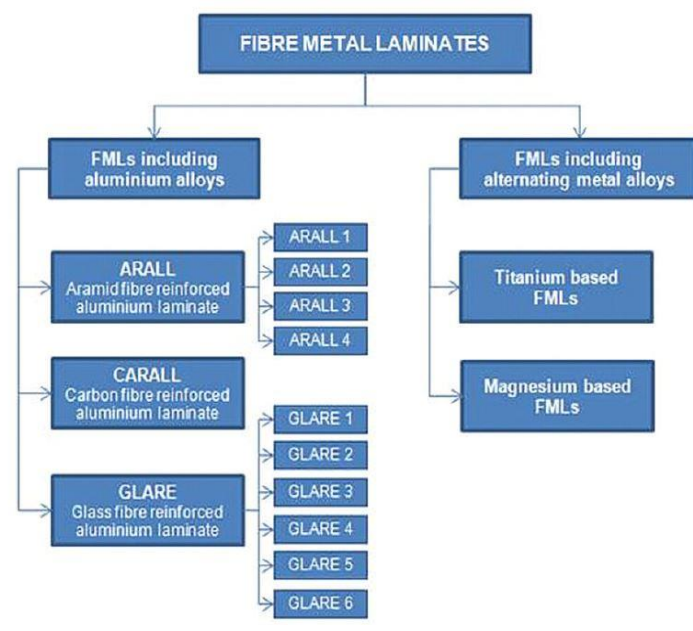

Gambar 2 Klasifikasi fiber metal laminates

ARALL1 merupakan struktur fiber metal laminates yang paling umum dibuat yang memiliki komponen penyusun serat aramid dan GLARE1 yang digabungkan pada fiber glass dengan kekuatan tinggi.
Pada struktur sandwich atau laminates permasalahan yang sering muncul adalah adanya delaminasi. Delaminasi adalah model kegagalan pada komposit yang berstruktur lapisan (layer). Penyebab delaminasi adalah karena lemahnya ikatan antar matrik dan layer pada komposit berstruktur laminate .Layeryang mudah terpisah maka mampu memperngaruhi kekuatan komposit itu sendiri (Cantwell \& Morton, 1985). Untuk meningkatkan ikatan antar layer dapat menggunakan perlakuan mechanical bonding [6].

Prasetyo (2015) menganalisis perbandingan metode pengujian kekasaran permukaan pada material polimer dan komposit. Kekasaran pada material polimer dan komposit diukur menggunakan 4 metode pengukuran yang berbeda, yaitu Tactile method (Profile Measurement), Focus variation (Areal measurement), Fringe Projection Technique (FPT) dan Confocal Laser scanning microscope method. [10]

Dengan memberikan kekasaran permukaan pada lapisan diharapkan mampu meningkatkan ikatan antar layer. Oleh karena itu pada penelitian ini digunakan variasi kekasaran permukaan aluminium pada struktur fiber metal laminates yang diharapkan dapat mempengaruhi kekuatan tarik material tersebut.

Pada penelitian ini jenis serat yang digunakan adalah serat karbon sebagai penguat pada struktur fiber metal laminates. Serat karbon, grafit karbon atau CF adalah bahan yang terdiri dari serat yang sangat tipis sekitar 0,005-0,010 mm dan sebagian besar terdiri dari atom karbon (Kopeliovich \& Dimitri, 2012). Atom karbon yang terikat bersama kristal mikroskopis yang sejajar dengan sumbu panjang serat yang membuat serat karbon merupakan serat yang sangat kuat untuk serat seukurannya. Beberapa ribu serat karbon dipintal bersama untuk membentuk sebuah benang, yang dapat digunakan dengan sendirinya atau ditenun menjadi kain.[4] Serat karbon (Gambar 3) memiliki banyak pola pintal yang berbeda dan dapat dikombinasikan dengan resin plastik dan dicetak untuk membentuk material komposit seperti plastik yang diperkuat serat karbon (CFRP) untuk membuat bahan yang memiliki strength-toweight ratio tinggi. Densitas serat karbon juga lebih rendah daripada densitas dari baja, 
sehingga ideal untuk aplikasi yang memerlukan bahan yang ringan. Dari uraian tersebut menunjukkan serat karbon berpotensi sebagai penguat atau inti pada FML.

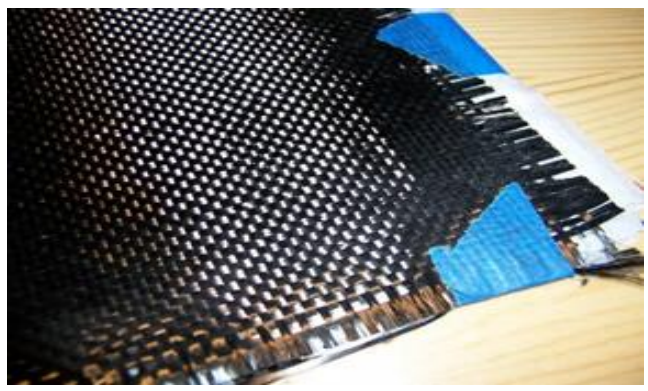

Gambar 3 Serat Karbon

Pengujian tarik bertujuan untuk mengetahui tegangan, regangan, modulus elastisitas bahan dengan menarik spesimen sampai putus. Hubungan tegangan dan regangan pada beban tarik ditentukan menggunakan rumus sebagai berikut (Surdia, 1995)

$F=\sigma \cdot$ A dengan $\sigma=F / A$

Nilai regangan adalah jumlah pertambahan panjang yang diakibatkan pembebanan dibandingkan dengan panjang daerah ukur. Nilai regangan ini adalah regangan proporsional yang didapat dari garis proporsional pada grafik tegangan-regangan hasil uji tarik komposit (Surdia, 1995)

$\varepsilon=\frac{\mathrm{l}_{i}-\mathrm{l}_{0}}{\mathrm{l}_{0}}=\frac{\Delta \mathrm{l}}{\mathrm{l}_{0}}$

Pada daerah proporsional yaitu daerah dimana tegangan-regangan yang terjadi masih sebanding, defleksi yang terjadi masih bersifat elastis dan masih berlaku hukum Hooke. Besarnya nilai modulus elastisitas yang juga merupakan perbandingan tegangan dan regangan pada daerah proporsional dapat dihitung menggunakan persamaan. (Surdia, 1995) [5]

$\mathrm{E}=\frac{\Delta \sigma}{\Delta \varepsilon}$

Pengujian tarik dilakukan menggunakan mesin uji tarik atau universal testing dengan spesimen uji mengacu pada standard ASTM D638-03. [3]

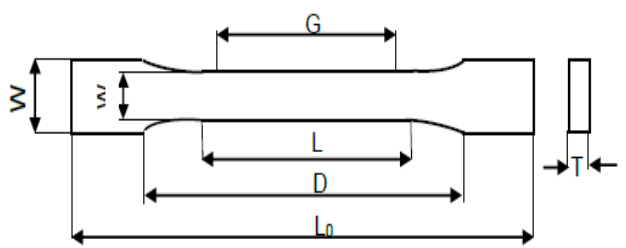

Gambar 4 Spesimen uji tarik ASTM D638-03

Tabel 1. Dimensi Spesimen Uji Tarik (ASTM D638-03)

\begin{tabular}{|c|c|}
\hline Dimension & Value, mm (in) \\
\hline Thickness $<7$ mm(0.28in), $T$ & $\begin{array}{c}32 \pm 0.4(0.12 \\
\pm 0.02)\end{array}$ \\
\hline Width of narrow selection, $W$ & $13(0.5)$ \\
\hline Length of narrow selection, $L$ & $57(2.25)$ \\
\hline Width overall, $W O$ & $19(0.75)$ \\
\hline Length overall, LO & $165(6.5)$ \\
\hline Gauge length, $G$ & $165(6.5)$ \\
\hline Distance between grips, $D$ & $115(4.5)$ \\
\hline Radius offillet, $R$ & $76(3.00)$ \\
\hline
\end{tabular}

\section{METODE PENELITIAN}

Sebelum dilakukan proses pembuatan komposit FML langkah pertama yang harus dilakukan adalah mempersiapkan aluminium terlebih dahulu. Perlakuan kekasaran permukaan pada aluminium dilakukan sesuai dengan variasi $R_{a}$ yang diinginkan dengan menggunakan sand blasting machine. Setelah proses sand blating selesai, langkah berikutnya yaitu dilakukan pengukuran kekasaran permukaan dengan surface roughness tester sehingga didapat variasi nilai $R_{a}$. Setelah proses pengukuran kekasaran permukaan, aluminium diberi perlakuan panas annealing dengan suhu $300^{\circ} \mathrm{C}$ selama 1 jam di dalam furnace agar struktur butiran aluminium homogeny dan menghilangkan tegangan sisa atau residual stress pada aluminium. Kemudian Aluminium dipotong sesuai standar spesimen uji tarik ASTM D638-03. Langkah berikutnya yaitu memotong carbon fiber dengan sudut anyam $45 / 45^{\circ}$ sesuai dimensi spesimen uji tarik ASTM D638-03. Setelah proses tersebut barulah proses pembuatan FML komposit dilakukan dengan menggunakan metode vaccum infusion. Karakteristik FML komposit diamati dengan pengujian tarik dan foto makro 
patahan untuk mengetahui area delaminasi pada fiber metal laminates.

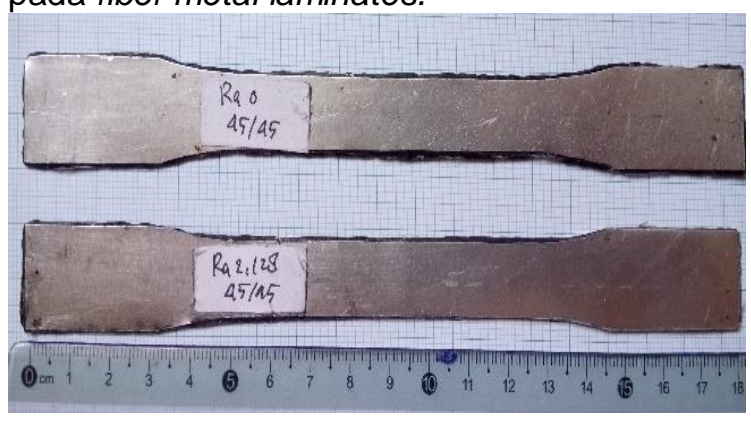

Gambar 5 Spesimen FML komposit

\section{Vacuum Resin Infussion (VARI)}

Metode VARI menghasilkan material komposit yang mempunyai rasio fiber- resin yang tinggi dibandingkan dengan metode hand lay-up. Metode hand lay-up menggunakan cara manual untuk mengalirkan resin, sedangkan pada metode VARI (Gambar 6) aliran resin dilakukan oleh tekanan vacuum yang konstan. Penggunaan tekanan vacuum konstan ini yang mengatur distribusi resin agar tetap dalam suatu jumlah tertentu. (Brouwer, et al, 2003). Hal ini menyebabkan rasio fiber-resin menjadi tinggi sehingga menghasilkan material komposit yang kuat dan ringan [9]
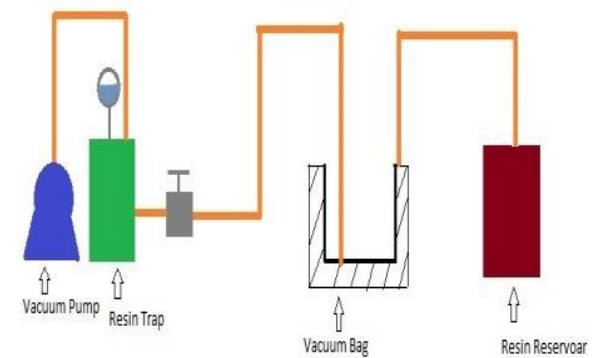

Gambar 6 Skema Vacum Ressin Infussion

\section{HASIL DAN PEMBAHASAN}

Setelah dilakukan pengujian tarik terhadap FML komposit dengan serat karbon tanpa sand blasting atau $R_{a} 0.33 \mu \mathrm{m}$ maka didapat hasil pengujian seperti pada gambar berikut:

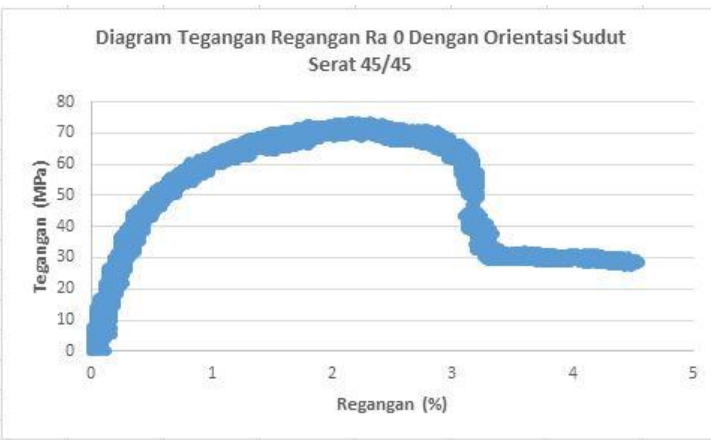

Gambar 7 Diagram Tegangan Regangan Spesimen FML dengan $R_{a} 0.33$

Berdasarkan Gambar 7 hasil pengujian tarik spesimen FML komposit tanpa kekasaran permukaan atau $R_{a} 0.33 \mu \mathrm{m}$, dapat diamati tegangan tarik meningkat sebesar $71.82 \mathrm{MPa}$ sejalan dengan meningkatnya regangan sebesar $2.3 \%$. Kemudian tegangan turun menjadi $27.3 \mathrm{MPa}$. Karakteristik diagram tegangan regangan pada variasi $R_{a} 0.33 \mu \mathrm{m}$ menunjukkan terjadinya slip antar Ipermukaan aluminium dan komposit serat karbon. Hal ini terjadi karena permukaan aluminium tanpa kekasaran memiliki morfologi yang rata dan teratur permukaannya sehingga matrik tidak bisa melakukan penetrasi pada permukaan yang rata sehingga tidak adanya mekanisme lock and key antar permukaan luar dan inti (core) struktur fiber metal laminates (FML) yang menyebabkan lemahnya ikatan antara permukaan aluminium dan komposit karbon pada struktur fiber metal laminates (FML).

Gambar 8(a) - 8(e) merupakan hasil diagram tegangan regangan tiap variasi kekasaran permukaan $\left(R_{a}\right)$ pada pengujian tarik.

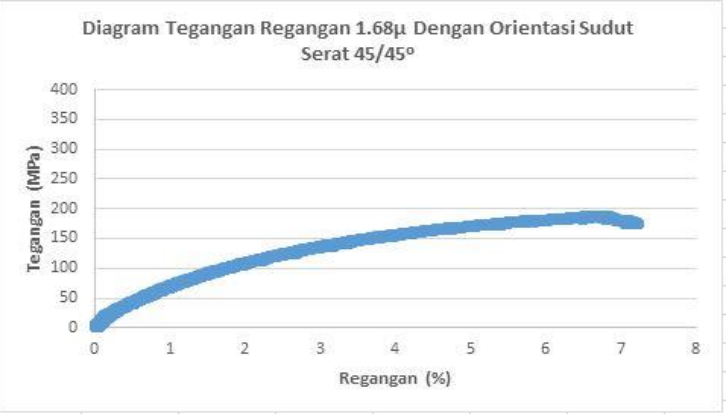

Gambar 8(a) Diagram Tegangan Regangan Spesimen FML dengan $R_{a} 1,68 \mu \mathrm{m}$ 


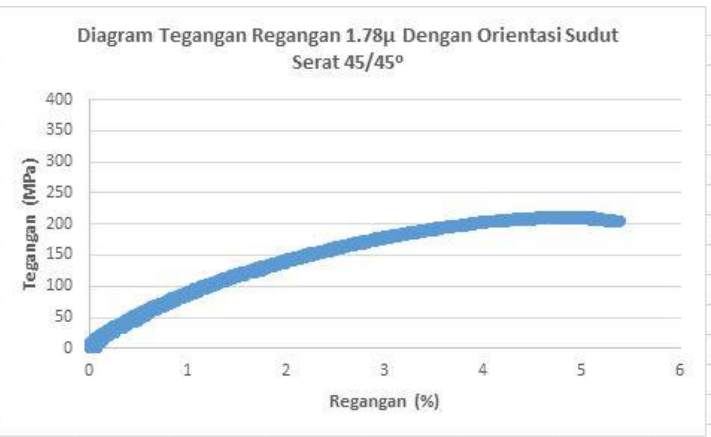

Gambar 8(b) Diagram Tegangan Regangan Spesimen FML dengan $R_{a} 1,78 \mu \mathrm{m}$

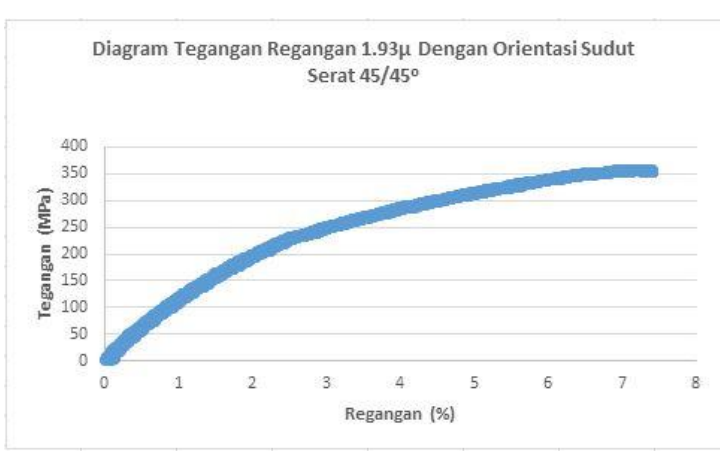

Gambar 8(c) Diagram Tegangan Regangan Spesimen FML dengan $R_{a} 1,93 \mu \mathrm{m}$

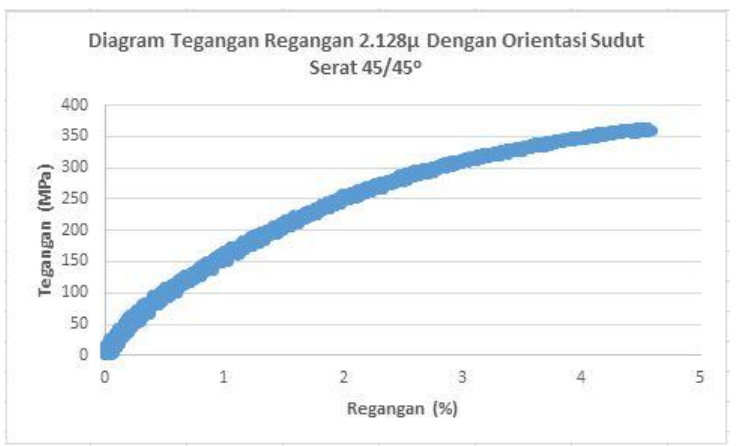

Gambar 8(d) Diagram Tegangan Regangan Spesimen FML dengan $R_{a} 2,128 \mu \mathrm{m}$

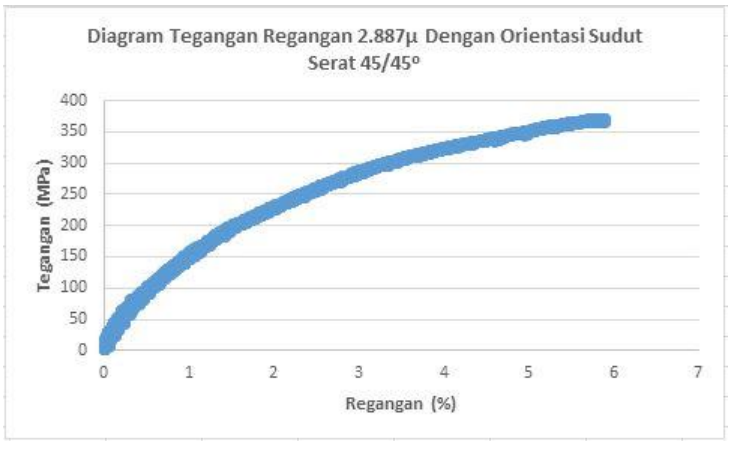

Gambar 8(e) Diagram Tegangan Regangan Spesimen FML dengan $R_{a} 2,887 \mu \mathrm{m}$

Diagram tegangan regangan pengujian tarik FML komposit dengan kekasaran permukaan (gambar 8(a) - 8(e)) memiliki karakteristik yang berbeda dengan diagram tegangan uji tarik FML komposit tanpa kekasaran permukaan atau $R_{a} 0.33 \mu \mathrm{m}$. Ini menunjukkan bahwa variasi kekasaran permukaan mempengaruhi struktur fiber metal laminates. Variasi kekasaran permukaan membuat morfologi permukaan aluminium menjadi tidak rata sehingga matrik mampu melakukan penetrasi pada permukaan aluminium yang tidak rata yang membuat mekanisme lock and key terjadi antar layer komposit karbon dan aluminium. Adanya kekasaran permukaan membuat ikatan antar layer semakin kuat karena adanya interlocking antar lapisan inti dan permukaan.

Hasil kekuatan tarik maksimal fiber metal laminates composite (FML) tiap variasi kekasaran permukaan $\left(R_{a}\right)$ dapat dilihat pada tabel 2, dan dapat dibandingkan langsung pada gambar 9 .

Tabel 2. Tabel Kekuatan Tarik Max Tiap Variasi $R_{\underline{a}}$

\begin{tabular}{|c|c|}
\hline$R_{a}(\mu \mathrm{m})$ & $\begin{array}{c}\text { Tegangan Tarik } \\
(\mathrm{MPa})\end{array}$ \\
\hline 0.33 & 71.82 \\
\hline 1.68 & 159 \\
\hline 1.78 & 227 \\
\hline 1.93 & 358 \\
\hline 2.128 & 361 \\
\hline 2.887 & 367 \\
\hline
\end{tabular}




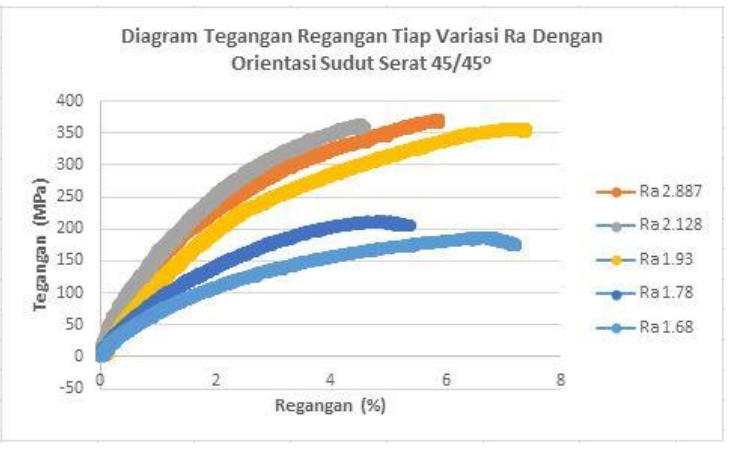

Gambar 9 Diagram Tegangan Regangan Spesimen FML Tiap Variasi $R_{a}$

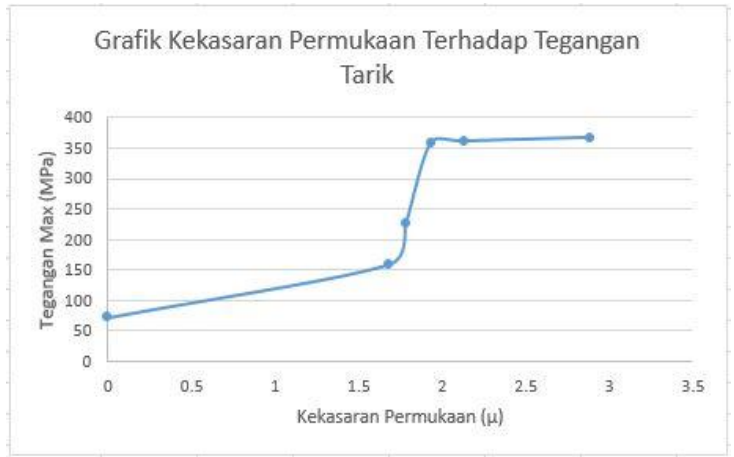

Gambar 14 Grafik kekasaran permukaan $\left(R_{a}\right)$ terhadap tegangan tarik max.

Gambar 14 menunjukkan bahwa kekasaran permukaan mempengaruhi kekuatan tarik FML komposit. Semakin besar nilai kekasaran permukaan $\left(R_{a}\right)$, kekuatan tarik komposit semakin tinggi. Ini diakibatkan semakin kasar permukaan maka ikatan antar lapisan inti (core) dengan lapisan permukaan (aluminium) semakin kuat, ini terjadi karena semakin meningkat nilai kekasaran permukaan maka morfologi permukaan aluminium menjadi tidak rata tau tidak teratur sehingga matrik mampu melakukan penetrasi pada permukaan yang tidak rata sehingga terjadi mekanika lock and key antar lapisan sehingga ikatan antar komposit serat karbon dan aluminium meningkat yang memengaruhi kekuatan tarik komposit. Kekuatan tarik maksimal FML komposit paling tinggi yaitu pada kekasaran permukaan $\left(R_{a}\right) 2.887 \mu$ dengan kekuatan tarik maksimal sebesar $367 \mathrm{MPa}$.

Kekuatan fiber metal laminates juga dipengaruhi adanya delaminasi pada spesimen. Delaminasi merupakan model kegagalan pada material komposit atau baja yang berstruktur laminasi (lapisan) [8]. Penyebab kegagalan ini bermacam-macam, yaitu bisa terjadi akibat beban siklik atau berulang, tumbukan (impact) dan pengaruh lainnya yang membuat antar lapisan terpisah, delaminasi terjadi karena lemahnya ikatan adhesive antar layer (Cantwell \& Morton, 1985).

Delaminasi juga terjadi pada struktur (FML) di penelitian ini (gambar 15(a)-15(f)). Cara mengetahui adanya delaminasi pada struktur FML penelitian ini dengan cara mencelupkan salah satu patahan tiap specimen pada tinta marker setelah pengujian tarik selama satu hari, kemudian ditunggu hingga kering. Setelah tinta marker pada ujung patahan specimen mengering maka langkah selanjutnya adalah mengelupas salah satu permukaan aluminium FML komposit dan dilihat seberapa luas area delaminasi yang terjadi pada patahan specimen seperti yang terlihat pada gambar berikut.

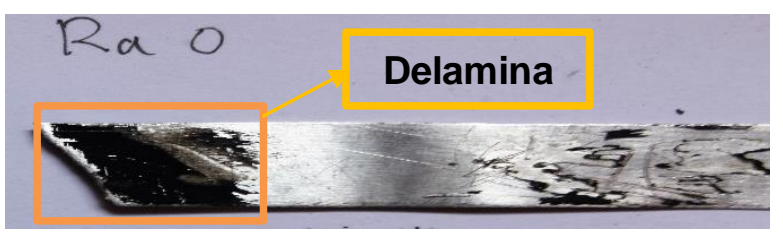

Gambar 15(a) Area delaminasi pada patahan spesimen uji tarik dengan variasi $R_{a} 0 \mu \mathrm{m}$

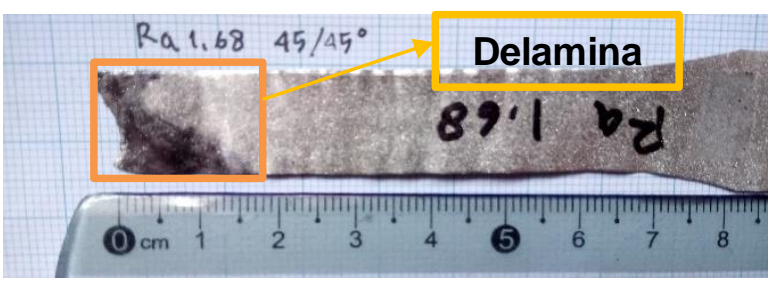

Gambar 15(b) Area delaminasi pada patahan spesimen uji tarik dengan variasi $R_{a} 1,68 \mu \mathrm{m}$

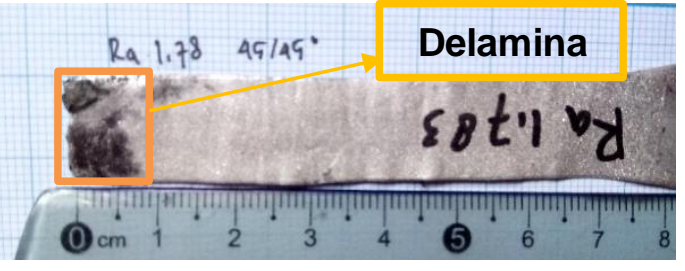

Gambar 15(c) Area delaminasi pada patahan spesimen uji tarik dengan variasi $R_{a} 1,78 \mu \mathrm{m}$ 


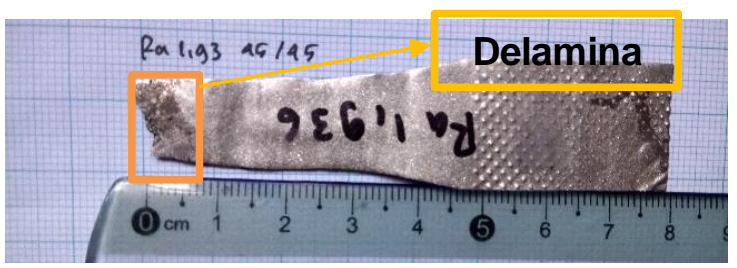

Gambar 15(d) Area delaminasi pada patahan spesimen uji tarik dengan variasi $R_{a} 1,93 \mu \mathrm{m}$

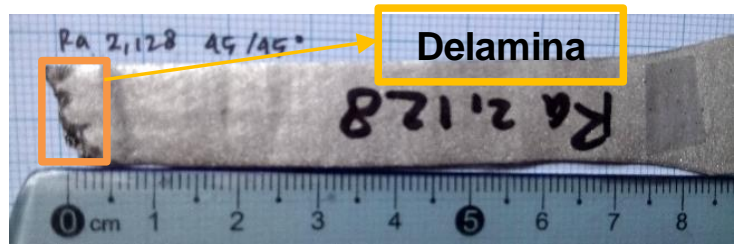

Gambar 15(e) Area delaminasi pada patahan specimen uji tarik dengan variasi $R_{a} 2,128 \mu \mathrm{m}$

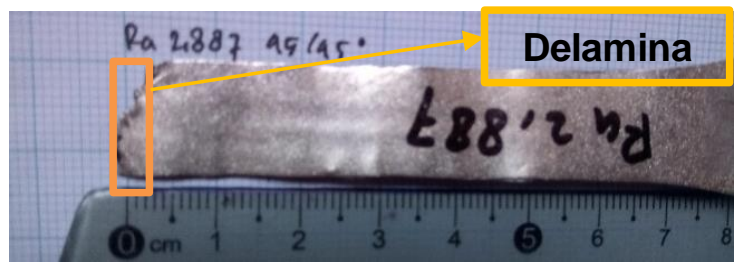

Gambar 15(f) Area delaminasi pada patahan specimen uji tarik dengan variasi $R_{a} 2.887 \mu \mathrm{m}$

Gambar 15 (a-f) menunjukkan area delaminasi yang terjadi pada specimen uji tarik tiap variasi kekasaran permukaan $\left(R_{a}\right)$. Luas area delaminasi yang terjadi dapat dihitung menggunakan software Image J. Tabel 3 adalah hasil perhitungan luas area delaminasi menggunakan software ImageJ

Tabel 3. Luas area delaminasi tiap variasi $R_{a}$

\begin{tabular}{cc}
\hline$R_{a}(\mu \mathrm{m})$ & $\begin{array}{c}\text { Luas Area } \\
\text { Delaminasi }\left(\mathrm{cm}^{2}\right)\end{array}$ \\
\hline 0 & 2.45 \\
1.68 & 1.25 \\
1.78 & 0.883 \\
1.93 & 0.687 \\
2.128 & 0.27 \\
2.887 & 0.156 \\
\hline
\end{tabular}

Dapat diamati bahwa semakin tinggi variasi kekasaran permukaan maka area delaminasi yang ditunjukkan anak panah semakin mengecil. Area delaminasi pada permukaan patahan spesimen uji tarik FML semakin mengecil diakibatkan karena semakin meningkatnya nilai kekasaran permukaan. Semakin tinggi nilai kekasaran permukaan maka ikatan antar layer inti (core) dan permukaan aluminium semakin besar dikarenakan mekanika interlocking antar lapisan semakin besar Jika mekanika interlocking antar lapisan semakin besar maka kekuatan tarik FML komposit juga semakin tinggi. Area delaminasi terkecil ditunjukkan pada gambar $16 \mathrm{f}$ dengan luas area delaminasi sebesar $0.156 \mathrm{~cm}^{2}$ pada variasi kekasaran permukaan $\left(R_{a}\right) \quad 2.887 \mu$ yang memiliki kekuatan tarik paling besar diantara keenam specimen uji tarik dengan nilai $367 \mathrm{MPa}$.

\section{KESIMPULAN}

Kekuatan tarik fiber metal laminates dipengaruhi oleh kekasaran permukaan $\left(R_{a}\right)$. Semakin tinggi nilai kekasaran permukaan maka kekuatan tariknya semakin besar. Kekuatan komposit tertinggi yaitu pada variasi kekasaran permukaan $2.887 \mu \mathrm{m}$ dengan nilai kekuatan tariknya sebesar $367 \mathrm{MPa}$.

Untuk penelitian selanjutnya untuk meningkatkan ikatan antar layer pada struktur fiber metal laminates dapat dilakukan dengan metode yang berbeda. Pada penelitian ini untuk meingkatkan ikatan antar layer dilakukan dengan menggunakan metode mechanical bonding, mungkin pada penelitian selanjutnya untuk meningkatkan ikatan antar layer dapat dilakukan dengan menggunakan metode chemical bonding atau electrostatic bonding.

\section{DAFTAR PUSTAKA}

[1] Zeke, Smith. (1996): Understanding Aircraft Composite Construction

[2] Matthews \& Rawlings (1993): Composite Materials : Engineering and Science

[3] Book Standard ASTM D638-03 (2003): Standard Test Method For Tensile Properties Of Plastics. ASTM International

[4] Kopeliovich \& Dimitri (2012): Carbon Fiber Reinforced Polymer Composites, Wayback Machine.substech.com

[5] Tata S. \& Saito S. (1995): Pengetahuan Bahan Teknik. 
[6] W.J. Cantwell \& J. Morton., [9] W.D. Brouwer*, E.C.F.C. van Herpt, M. (1985):Detection of Impact Damage in CFRP Laminates, ElsevierComposite Structures 3 (3-4), 241-257

Labordus.(2003):Vacuum injection moulding for large structural applications. Elsevier LTD

[7] Tamer Sinmazcelik dkk. (2011):Fiber [10] Prasetyo, Dimas Eko (2015) : Analisis metal laminates, background, bonding, and applies test methods, 2011

[8] W.J. Cantwell \& J. Morton., (1991): The impact resistance of composite materials. Elsevier composites 22 (5), 347-362.

Perbandingan Metode Pengujian

Kekasaran Permukaan pada Material Polimer Dan Komposit, Jurnal Rekayasa Mesin UB Vol 6 no 3 